\title{
Group of experience with the elderly: psychosocial support in health promotion
}

\author{
Grupo de convivência de idosos: apoio psicossocial na promoção da saúde
}

\author{
Grupo de convivencia de ancianos: apoyo psicosocial en la promoción de la salud
}

Laudicéia Noronha Xavier ${ }^{1}$, Isabelle Cordeiro de Nojosa Sombra² ${ }^{2}$ Annatália Meneses de Amorim Gomes ${ }^{1}$, Gisele Lopes Oliveira ${ }^{1}$, Cryslany Portela de Aguiar ${ }^{3}$, Rômulo Mágnus de Castro Sena ${ }^{4}$

Objective: to analyze the perception of the elderly on the importance of a group of experience. Methods: ilt is an exploratory, descriptive research with qualitative approach, developed at a Basic Health Unit in a county of the Brazilian northeast, with 13 elderly people attending the Group. Data were collected through semi-structured interviews and analysis by the thematic analysis technique. Results: three empirical categories were identified: motivation to seek the group of experience, perspective concerning this group and changes perceived through participation. Conclusion: the group of experience can represent a therapeutic moment for the elderly, serving as support and strengthening the elderly in the social context, making the improvement and development of abilities as well as the obtaining more knowledge for health promotion possible.

Descriptors: Aged; Health Promotion; Social Group; Nursing; Social Support.

Objetivo: analisar a percepção de idosos sobre a importância do Grupo de Convivência. Métodos: pesquisa exploratória, descritiva, com abordagem qualitativa, desenvolvida em uma Unidade Básica de Saúde em um município do nordeste brasileiro, com 13 idosos que frequentavam o Grupo. Coleta dos dados por meio de entrevista semiestruturada e análise mediante técnica de análise temática. Resultados: foram identificadas três categorias empíricas: motivação ao procurar o grupo de convivência, perspectiva em relação a este e mudanças percebidas pela participação. Conclusão: o grupo de convivência pode representar um momento terapêutico para idosos, servindo de apoio e fortalecendo o idoso no contexto social, tornando possível o aprimoramento e o desenvolvimento de habilidades e obtenção de mais conhecimentos para promoção da saúde.

Descritores: Idoso; Promoção da Saúde; Grupo Social; Enfermagem; Apoio Social.

Objetivo: analizar la percepción de ancianos sobre la importancia del Grupo de Convivencia. Métodos: investigación exploratoria, descriptiva, cualitativa, desarrollado en una Unidad Básica de Salud en una ciudad del noreste brasileño, con 13 ancianos que frecuentaban el Grupo. Recolección de datos a través de entrevista semiestructurada y análisis por la técnica de análisis temático. Resultados: se identificaron tres categorías empíricas: motivación para buscar el grupo de convivencia, perspectiva en relación a esto y cambios percibidos por participar. Conclusión: el grupo de convivencia puede representar un momento terapéutico para ancianos, que sirve de apoyo y fortalecimiento del anciano en el contexto social, por lo que es posible mejorar y desarrollar habilidades y obtener más conocimientos para promoción de la salud.

Descriptores: Anciano; Promoción de la Salud; Grupo Social; Enfermería; Apoyo Social.

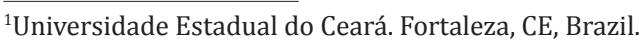

${ }^{2}$ Centro Universitário Estácio. Fortaleza, CE, Brazil.

${ }^{3}$ Universidade Estadual Vale do Acaraú. Sobral, CE, Brazil.

${ }^{4}$ Universidade Federal do Rio Grande do Norte. Natal, RN, Brazil.

Corresponding author: Laudicéia Noronha Xavier

Av. Mãe Rainha, 228, Renato Parente, CEP: 62033010. Sobral, CE, Brazil. E-mail: laudiceianx@hotmail.com
} 


\section{Introduction}

The Family Health Programme was established in 1994, after the implementation of the Unified Health System by restructuring the movement of care model to health in Brazil. It emerged as a form of reorganization of health care, seeking to operationalize the principles of the Unified Health System in the context of Primary Care $^{(1)}$.

The Primary Care is the preferred gateway to the National Health System, and the starting point for the structuring of local health systems. It is represented by a set of actions, both individual and collective, with promotion and health protection activities to be developed, aimed at disease prevention, diagnosis, treatment, rehabilitation and maintenance of the health of the population ${ }^{(1)}$.

In 1997, a county located in the countryside of Ceará implemented the Family Health Strategy actively in primary care, with the creation of 31 Family Health Teams, consisting of one doctor, one or two nurses, nursing assistants and health community workers, providing the coverage of the population in the county, which has 57 Family Health teams, distributed in 32 health centers ${ }^{(2)}$.

Indeed, the Primary Care National Policy expresses guidelines that guide the reorganization of care of health services at all levels of care, considering care as the axis of reorientation of the model, bringing the proposal for humanization of development actions and health services ${ }^{(2)}$.

Brazil, previously considered a "young country" is seen by the World Health Organization as a nation with structures of aging. It is fundamental that the society in general understands aging, in order to create intervention policies together with the government for the creation of decent and humane future for all the elderly ${ }^{(3)}$.

Aging, a natural and gradual phenomenon of human life, causes neuromuscular and physiological changes that can trigger physical limitations. Dealing with aging is a challenge to be faced by the Brazilian population as a result of several factors involved, namely the ones of biological, psycho-emotional, socio-cultural and educational nature ${ }^{(4)}$.

The term 'third age', replacing the term "old age", was adopted to define the age range starting at 60 , and is accepted by the World Health Organization, by characterizing a milestone in human life. In society, the situation of those who are in this age range is quite complex and it is more difficult in cases where the elderly, regardless of social class, health status, dependency status, gender, employment status and place of residence, denies aging for several reasons. Indeed, it is observed that women care about their body and appearance and therefore the industry of beauty, the ideal of the perfect body, stimulates the purchase of products against wrinkles and sagging through the consumption of vitamins, cosmetics and physical activity. Thus, one can think of third age as "lack of chronology" of life ${ }^{(5-6)}$.

Data from the Brazilian Institute of Geography and Statistics report that the Brazilian elderly population has increased considerably from 1999 to 2009 , rising from 6.4 to 9.7 million. The proportion of the elderly increased from $12.6 \%$ of the population in 2012 to $13 \%$ in 2013, favoring the increase of life expectancy of the Brazilian to 74.08 years in 2011. Concerning the Government, this worry was inexistent before, since, as age advances, changes in standards of health and functional capacity occur, which raises some questions: what is the impact of a group of experience for the elderly? How can the group of experience help in promoting health of the elderly? ${ }^{(7-9)}$.

It is necessary to cover these points, since the pursuit of healthy aging is a constant concern in our population. Besides that, health professionals, especially nurses, need to be aware of their role with the elderly, so that the promotion of their health is satisfactorily developed. It is important to consider the fact that activities in the group can contribute for the guidelines and development of the health education through meetings as a complementary area for the 
exchange of information and social stimulus, ensuring a protective environment for the elderly, helping in their daily activities in the scope of the family and the community; they also have an emotional charge, which favors the improvement of health and living conditions for the development of the autonomy of the elderly ${ }^{(10)}$.

The first scholar to use group activities with alcoholic people used a methodology based on discussions between doctors and patients. So, the promotion and health protection to be performed for and with the elderly in the groups of experience are intended to establish social relations whose function is to provide the opportunity to build emotional mobilizations to the participants, reflecting knowledge and practices in health which can provide the increment of the functional capabilities of people using contents available in the community, aimed at reducing risk factors which constitute a threat to their health and can guide them with educational-

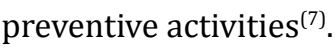

The groups provide experience and practice of the several recreational, cultural and religious activities, besides promoting experiences in the group process in different ways, when sharing these experiences with each other, exploring their potentials, promoting the control, prevention and treatment of possible psychosocial disorders, such as depression. In the contact with the elderly, bonds are created which make social inclusion possible ${ }^{(7)}$.

The relevance of this study lies in the possibility of developing support groups for the elderly, based on the knowledge arising from the population itself. In addition, through the understanding that there are great challenges in health promotion and in the acceptance of the elderly concerning their own aging, the group can contribute when reviewing the importance of living with pleasure, dignity and wisdom.

Considering what has been reported so far, this study aimed at analyzing the perception of the elderly on the importance of a group of experience.

\section{Method}

This study is an exploratory, descriptive research with qualitative approach, developed at a Basic Health Unit in a county in the countryside of Northeastern Brazil.

Participants were 13 elderly who attended the group of experience, which included those who were part of the group from the beginning, nine years ago, and agreed to participate in the study.

Since its implementation, the group is led by nurses, with the contribution of other professionals, being a weekly educational space for health promotion and in which the planning of activities to be developed occurs according to a prior schedule, involving activities of group dynamics, educational lectures, conversation groups, activities that provide healthy habits (relaxation, postural hygiene, memory workshops, fitness, leisure), social and citizenship rights, explanation of prevalent chronic diseases such as hypertension, diabetes, leprosy and tuberculosis; in the course of the activities, there were other demands at the request of the elderly and other needs of the health unit.

The technique used for data collection was a semi-structured interview, made from September to October 2014. Audio recording was used, guided by an instrument consisting of two open questions: What motivated you to seek a group of experience? What changed in your life for participating in the group of experience?

Each participant underwent a single interview with an average duration of 11 minutes. Their statements were transcript by a digital recorder with their words, without gaps, not considering behaviors and mannerisms of the elderly.

Data were analyzed using thematic analysis, for being considered an adequate instrument to the speech of variable content, as in the case of this study. The concern with the reality that cannot be quantified, that is, working with the nuclei of senses which make up communication due to the frequency 
in which the topic is repeated in the statements of the interviewees, being understood in a pre-analysis, exploration of the material, treatment of the results and interpretation ${ }^{(11)}$.

The pre-analysis is the time to organize the collected material from the transcript of the statements and the responses to the questionnaire. It was organized in order to operationalize and systematize initial ideas. Afterwards, the brief reading, that is, the first contact with the texts to absorb the entire contents of the field, was made, the moment in which the corpus of this study was defined. The cuttings of the corpus of the text were made from the guiding question, meeting the objective of this study. As the themes were repeated more frequently, rates were listed $^{(11)}$.

The exploitation of the material corresponds to the time of organization of the content of the statements into categories, in which the data are refined to a better understanding of text meaning. In the first instance, the segments which were relevant in the text were handled, for example, a word, a phrase, a theme, an event in order to define the counting rules, and finally, classify and add the data responsible for the specification of the themes in the theoretical or empirical categories ${ }^{(11)}$.

The treatment of the results, interpretation occurs at the time in which the interpretation of the raw data is made, establishing the chart of results, highlighting the information provided by the analysis. Qualitative inferences were made, using the meanings instead of statistical inferences. When the interpretations were made, there was an interrelation with the theoretical framework initially designed or opening new tracks around the new theoretical dimensions, suggested by the reading of the material. To preserve the identity of the participants the letter $\mathrm{E}$ and a number was assigned to each elderly ranging from 01 to 13, according to the development of interviews: E1, E2 and so on. The comparison of the data obtained with the theoretical foundation allowed the interpretation to make sense. Interpretations lead to inferences that seek what is hidden by the apparent reality in an attempt to transform raw data into meaningful ones ${ }^{(11)}$.

This study was based on the basic principles of Bioethics, recommended in Resolution 466/12 of the National Health Council, which have guidelines and regulations involving human research, considering the perspective of people and the communities, according to the mentioned assumptions of bioethics - autonomy, non-maleficence, beneficence, justice and equity. The making of the research was supported by the Committee of Ethics and Research of the Universidade Federal do Ceará, Brazil, under legal opinion number 660,902 .

\section{Results}

Of the 13 elderly of the research, 11 were women, aged ranging from 64 to 87, average of 67 years; 2 men, aged ranging from 68 to 77 years. All participated in the group of experience of elderly people, simple people with low education level (ten of them had less or up to three years of schooling), and their stories of life were portrayed with much struggle and suffering in the pursuit of a better life.

Most of the elderly (nine) lived in households where they live with five people in average, having the pension fund as the only source of income. In addition, the elderly lived in the neighborhood with limited access to housing, education and health, with little economic condition (two of them had a family income of up to two minimum wages).

The statements of the elderly interviewed conducted the study for the following categories: motivations to search for the group of experience, perspective in relation to the group of experience, changes perceived by the participation in the group.

\section{Category 1: Motivations to search for the group of experience}

The reasons of the elderly in the search of the 
group are the conditions of living with health support, binding and social commitment.

Most of them believed that they would have more health, social support and knowledge to deal with the disease, with the conviction that the access to doctors, medicines, other professionals and services of the basic units would be easier to attend the meetings, as it is expressed in the statements: I looked for the group, once I felt that getting involved with those people, I was going to be healthier (E1). I was sick, I went to the group to know more, to get distraction, to leave home (E6). I have fun in participating in the group, when I don't come, I get sad (E 11).

The social connection of the elderly is weakened concerning their social and economic activities. The bonds with the family members were lost over the years as well as the sense of belonging to the household and actually there was a feeling of exclusion. Thus, the conflicts generally occurred once there is no appreciation of the elderly by young people, besides the fact that their pension fund is the only source of income in the house. Living inside the house made me very stressed, I was afraid of my son who uses those things, asking for money to buy more, the red eye and aggressive with me and thanks to the group, I can say that I'm another person (E6). The group helps me keep my mind busy with something, once the problems of the house with the, grandchildren, makes me discouraged (E5). I keep looking at the calendar and the watch to see the days passing by, the time I spend to come here is good for me. I get happy. It seems like I have no problem at home. The group is very good (E 10).

But the group is portrayed as a place of multiple possibilities of binding and social commitment from the moment in which the communication between the elderly and the professionals proposes congregation, providing encouragement to cope with solitude in an attempt to overcome social isolation. I have more zest for living. When I get here I feel light and happy (E3). Living alone is very bad, I suffer with solitude, but here I get very happy and I have fun with my friends and the professionals (E1). Because I have more people to talk to, to give me more encouragement, I feel well because I have been feeling down (E9). The group helped me to talk more with my family and now they listen to me more (E11).

Through groups of experience new opportuni- ties arise for the elderly, how to find people and thus strengthen the bonds of friendship, thus arousing the interest in social commitment, increasing their participation. I have a weekly commitment to be here. I feel good when I come here (E9). The group provides the opportunity for us to make new friends (E1).

\section{Category 2: Perspective in relation to the group of experience}

For older people, the group of experience is a place of learning and emotional support.

Through educational lectures, the professionals guide them about balanced nutrition, knowledge about the disease and the development of handicrafts.

Despite the fact that the interviewees receive information on the change of habits, they feel difficulties as follows: The nurse told me to eat leaves. We are not chameleon (E2). The nurse told us to eat six times a day, but you cannot eat without being hungry (E3).

Two of the interviewees in the group contributed with others from the general notions of prevalent chronic diseases: I was at home doing household chores and my heart started beating very fast. It was the pressure. I went to the health unit and it was 20 (E6). At home I was working in the orchard and the henhouse, I forgot to take the diabetes medicine, I was weak, I went to the doctor and the exam showed 400 for diabetes (E1). The guidance received in the group was fundamental for the elderly to look for the health unit in time. It was evident that the support for health covers other aspects besides the physical one and this makes them perceive other needs. Concerning the process of getting sick, one of them describes their problems to the professionals and to their friends: $I$ was taking a shower, I felt dizzy, I sat down and felt dizzy, I went to the hospital, I had a crooked mouth. It was the beginning of a stroke (E2).

It has been found the fact that, over the years, a group of manual activities was highlighted, even by their intellectual level, who could not develop more complex activities involving reasoning and comprehension. There was the possibility that they were able to learn to do something new, emerging 
a sense of self-worth: I learned to make the broom with pet bottles, previously I did not know, I say that I learned a lot here (E10). I cannot read or write, but I have a good memory and all that is taught to me I learn fast (E11). I tried to learn things, I cannot read and write very little, I like to learn, I was brought up making handicrafts (E6). I can say that I had a sleeping gift, the group awoke my gift, today I make handicrafts such as bedspread, cushions, with the pieces of cloth, I get happy, I have a lot of pleasure in making these things (E13). I always try to be alert for the day I meet the group, once through it, I could learn many things concerning handicrafts (E4).

It was observed that the emotional health of the elderly was well expressed when informed that their participation in the group provided relief of the pain and psychological distress when chatting, making friends, exchanging experiences, carrying a positive effect to the group, providing new opportunities of choices: For me, the group works as a therapy, it improves the condition of my head (E3). Before, I was nervous, an agony in my head, I can say that now I have more peace, my talent is surfacing every day, I can say that at the age I am, 71 years, I am happier now than when I was younger (E7).

\section{Category 3: Changes perceived by the participation in the group}

The elderly had the opportunity to improve their health and the group activities made them perceive themselves as valued people for the society.

One of the ways for the elderly to follow their health condition is through their performance in everyday activities. The support coming from the group contributes to the health and provides guidance on changes in their lifestyle. I had joint pain all the time and participating in the group with exercises was very good, today I can say I feel much better (E1). I felt backache for many years, pain in the legs, in the knees and following the group, talking to the people in the group, I no longer feel those things (E3). As time went by I observed changes in my body, before I had no strength in my legs to go walking, today I go downtown walking and do not get tired (E10).

The evolution of attitudes, behavior, gestures and looks of the elderly was perceived in the group, facing their shyness due to the fact it became easy to keep dialogs, interacting and sharing life experiences with the others. After I started attending the group I got happier and free to participate in other things (E6). I was very shy, I had difficulties in making friends, as time went by, I began to value all of these things (E7).

\section{Discussion}

In the group of the elderly, there is the opportunity to describe the diseases of their limbs so that they can identify problems, recognize complications. Besides that, it entails knowledge and reinforces preventive actions of control and wider explanations concerning their health, so that they can enhance their actions to promote health ${ }^{(8)}$.

The professionals with interventionist attitude can provide a range of information for the elderly to instrument them in order to make them reflect on their reality of life and their culture. Through this activity, the elderly can find stimulus to participate in the educational process, elaborating and making questions when necessary ${ }^{(12)}$.

Concerning the social commitment, it is observed that most of the interviewees spend most of their time at home. They are retired and their social activities are church services, and household chores only, and there is no more activity to give them the feeling of being involved. With the group, there was a fixed day and time established in a systematic way, which aroused the social commitment in them, encouraging them to think about important values of inclusion and participation.

In addition, the group of experience acquires remarkable importance for the elderly to face life with another perception, from the moment they are able to solve their problems according to their culture, to find incentives for a healthy social life, with leisure, to find people with similar conditions, sharing various subjects, learning to exercise their citizenship and how to contribute to the common good.

The fundamental keys in the development of educational activities are the elderly and the 
health professionals, especially nurses, denoting the importance of each one, with the increase of the experience, formation of the bond and the possibility of learning together, so that they can have more meetings, besides the ones already experienced in conventional individual appointments. The educational process, collectively, provides more expectation in the group environment, stimulates the exchange of ideas and, with that, the increase of the critical consciousness of its participants and the search for autonomy ${ }^{(7)}$.

The elderly feels welcomed and valued, encouraging the development of trust among these professionals who are so necessary and beneficial in the care process ${ }^{(13)}$. So if any of these agents is not committed to the smooth running of the process of realization of the group of experience, they will hardly reach the desired success ${ }^{(12)}$.

The community has its role of valuing the health and the social relations and activities in order to provide sense to their lives, and make them remember the importance of giving life to the days, not days to the life ${ }^{(14)}$.

One can see that there are factors that could interfere with the action of families as support to their elderly members, such as the separation of children, of women's work who never married or never had children, the traditional caregivers to family members. Hence the importance of the groups of experience as social domains so that they can foster social relations of the elderly through a qualified listening to their problems $^{(5)}$.

Failure in appreciating the speech of the elderly can jeopardize the treatment, while the recognition of their speech can contribute to the encouragement of their autonomy and the improvement of their quality of life. When considering the importance of the listening in the conduction of the health-disease process, there is the consideration of the person as a character of his illness ${ }^{(7)}$.

Regarding social commitment, the support from the groups contributes to the mental health and psychological well-being, helping the nonpharmacological treatment of anxious and depressive patients.

When you are in a group, you start developing bonds, strength, peace and new behaviors until you reach the point of belonging to it, as a person, with beings of several areas of sociability and with social representations which search a style life, which gathers pleasure and does not exclude the traditional standards of living in public ${ }^{(15)}$.

Thus, the elderly can arouse greater respect to others with attitudes socially accepted in the group of experience. Through communication and relationship, they differ from each other, guide the behavior, fears, motives, joys, and experience and settle experiences. Through communication with others, it is possible to exist in the sense of perceiving the other and how each one shows himself. The feelings are expressed through the exchange of subjectivities. Affection is fundamental to understand and perceive the other ${ }^{(16)}$.

Based on this thinking, educational activities aimed at health promotion can be exercised through formal practices, such as lectures and actions developed in daily life, which can provide satisfaction to the elderly ${ }^{(17)}$.

The elderly perceive the group as a kind of emotional support, exposing their feelings regarding their participation in the group of experience. The social world is closely related to the others and is organized into fields. It can motivate to take decisions, to forgive, to learn the new; the world of contemporaries, who live in "my" time and domain with the world of the ones who preceded and the ones who will succeed "us". Due to these relations there are several degrees of intimacy and anonymity ${ }^{(16)}$.

Working in the group with people provides one more aspect: the fact that they live the same experience in their daily lives can help them to jointly discover strategies which are shared to modify reality ${ }^{(18)}$.

A resource to be used to promote the care and learning is the interpersonal relationship that 
there is in the group of Health Education ${ }^{(19)}$. The Unified Health System, through its principles and guidelines, historically, search the encouragement of participatory management; It seeks to stimulate the active participation of the elderly in order to achieve higher levels of autonomy and consequently hence health, providing positive transformations ${ }^{(13)}$.

The life of the elderly, prior to the participation in the group was very restricted. Facing this reality, there was no time invested to awaken personal pleasure. Despite their low education, their precarious socioeconomic status and low pay, and thanks to their effort, they can still have an income that can provide them the basics things for life. For many years, however, the pleasures that could provide joy, happiness were sleeping and the group of experience brought forth a range of unique feelings.

The meeting in the group can awaken an emancipatory action when acquiring knowledge because they exercise their feelings, they find a range of social practices and sensations that still intend to live and transmit this knowledge to their community. Thus, educational lectures provide standards on how to obtain improvements in health, how to proceed with food, with the disease, combining the activities offered during the meetings, allowing most of them to identify changes in their health ${ }^{(8)}$.

So it is extremely important that the nurse uses educational practices in health that are dialogic, to a teaching-learning process directed to the reality of the elderly, valuing their life story and autonomy, inasmuch as the mutual respect among people favors the practice of a shared education ${ }^{(20)}$.

In the groups, there is a pedagogical action and at the same time, therapeutics, favoring the Health Promotion which has, among its characteristics, the enhancement of the competences to overcome difficulties, ability to widen consciousness thus promoting the transformation of attitudes facing the situation of health-disease ${ }^{(19)}$.
Therefore, working with groups needs to be open to these connections of the subjects, who long for them, posing as poietical-existential catalysts of duties which insist on expressing themselves. What the elderly describe is the possibility of the group of experience to be installed in their daily lives, to get in touch with movements from diversified flows, dimensions of the existence hitherto not included in their lives ${ }^{(4)}$.

Many of the interviewees were widows who for years developed the role of a woman, wife and a housewife. When they realize that they belonged to the "third age", they saw the opportunity to participate in the group in the pursuit to share knowledge, to have support and a chance to improve their health, self-esteem and acceptance in society. In their minds, they started having the comprehension of citizenship, contributing to the common welfare, and perceived the meanings that before could only have been obtained descriptively, compared the behaviors and their symbolic forms ${ }^{(15)}$.

\section{Conclusion}

The data collected from the perception of the elderly about the importance of the group of experience showed that the group is a space that provides fellowship and interaction of these with subjectivity in the creation of new social identities.

In this context, we observed that the elderly had the social and emotional support and knowledge to cope with the disease; they were helped to develop intellectual activities to learn something new from the educational lectures, and the possibility of improvement of new skills and knowledge about their health and the community, promoting their appreciation and so they became multipliers. For the elderly, the group was important in changing attitudes in order to obtain a life with more autonomy and quality. 
This study was limited only to a basic health unit in the county. Thus, we consider it as one more contribution to research in old age, facing the demographic demands of this segment in relation to the young population and a stimulus for the development of future works. Further researches must be made, concerning this topic. It is worth highlighting that nursing professionals when working with the elderly, must have a careful look on aging and on the educational practices developed in groups of experience, once they represent a population that has life experience and potentialities, which can be offered to the society.

\section{Collaborations}

Xavier LN, Oliveira GL and Aguiar CP participated in the conception of this study, collection, analysis and interpretation of the data. Sena RMC participated in the writing of the article and in the approval of the final version to be published. Sombra ICN and Gomes AMA contributed for the analysis, interpretation of the data and writing of the article.

\section{References}

1. Ministério da Saúde (BR). Política Nacional de Atenção Básica. Brasília: Ministério da Saúde; 2012.

2. Freitas CASL, Albuquerque IMN, Gifoni DP, Santiago AX, Silva MJ. Atenção à saúde do idoso na estratégia Saúde da família, Sobral-CE. Ciênc Saúde Coletiva. 2010; 7(43):200-5.

3. Santos NF, Silva MRF. As Políticas públicas voltadas para o idoso: melhoria da qualidade de vida ou reprivatização da velhice. Rev FSA. 2013; 10(2):358-71.

4. Almeida EA, Madeira GD, Arantes PMM, Alencar MA. Comparação da qualidade de vida entre idosos que participam e idosos que não participam de grupos de convivência na cidade de Itabira-MG. Rev Bras Geriatr Gerontol. 2010; 13(3):435-43.
5. Guerra ACLC, Caldas CP. Dificuldades e recompensas no processo de envelhecimento: a percepção do sujeito idoso. Ciênc Saúde Coletiva. 2010; 15(6):2931-40.

6. Areosa SVC, Benitez LB, Wichmann FMA. Relações familiares e o convívio social entre idosos. Texto Contexto Enferm. 2012; 11(1):184-92.

7. Tahan J, Carvalho ACD. Reflexões de Idosos Participantes de Grupos de Promoção de Saúde Acerca do Envelhecimento e da Qualidade de Vida. Saúde Soc. 2010; 19(4):878-88.

8. Rizolli D, Surdi AC. Percepção dos idosos sobre grupos de terceira idade. Rev Bras Geriatr Gerontol. 2010; 13(2):225-33.

9. Camargos MC. Estimativas de expectativa de vida com doenças crônicas de coluna no Brasil. Ciênc Saúde Coletiva. 2014;19(6):1803-11.

10. Camacho ACLF, Coelho MJ. Políticas Públicas para a Saúde do idoso: revisão sistemática. Rev Bras Enferm. 2010; 63(2):279-84.

11. Minayo MCS. 0 desafio do conhecimento: pesquisa qualitativa em saúde. São Paulo: Hucitec; 2010.

12. Nascimento DDG, Oliveira MA. Reflexões sobre as competências profissionais para o processo de trabalho nos Núcleos de Apoio à Saúde da Família. Mundo Saúde. 2010; 34(1):92-6.

13. Ohara ECC, Saito RXS. Saúde da família: considerações teóricas e aplicabilidade. São Paulo: Martinari; 2010.

14. Silva HS, Gutierrez BA. Dimensões da Qualidade de vida de Idosos, Moradores de rua de São Paulo. Rev Saúde Soc. 2013; 22(1):148-59.

15. Vasconcelos DS. De volta aos embalos de sábado à noite: a dança de salão na terceira idade. Curitiba: CRV; 2012.

16. Ribeiro JP, Rocha SA, Popim RC. Compreendendo os significados de Qualidade de vida segundo Idosos portadores de Diabetes Mellitus Tipo II. Esc Anna Nery. 2010; 14(4):765-71.

17. Nery NG, Marcelo VC, Dantas MAA. A satisfação de idosos quanto à Estratégia Saúde da Família, a partir da atenção em Saúde Bucal. Rev Bras Ciênc Saúde. 2010; 4(1):43-50. 
18. Wichmann FMA, Couto NA, Areosa SVC, Montañés MCM. Grupos de convivência como suporte ao idoso na melhoria da saúde. Rev Bras Geriatr Gerontol. 2013; 16(4):821-32.

19. Stotz EM, David HMSL. Educação popular e saúde. In: Soares CB, Campos CMS. Fundamentos de saúde coletiva e o cuidado de enfermagem. São Paulo: Manole; 2013. p.75-103.
20. Menezes Júnior JE, Queiroz JC, Fernandes SCA, Oliveira LC, Coelho SQF, et al. Educação em saúde como estratégia para melhoria da qualidade de vida dos usuários hipertensos. Rev Rene. 2011; 12(n.esp.):1045-51. 